\title{
Carriage rate and methicillin resistance of Staphylococcus aureus in food handlers in Kars City, Turkey
}

\author{
Leyla Vatansever*, Çiğdem Sezer and Nebahat Bilge
}

\begin{abstract}
The aim of this study was determine carriage rate and methicillin resistance of Staphylococcus aureus among food handlers. Samples were collected by swabbing the mouth, nasal cavity and hands of food workers. The isolation of $S$. aureus was performed using a culture method and verified by using a genetic method (PCR). The presence of mecA gene was analysed by PCR. The fourteen antimicrobial disks were also used to determine antimicrobial susceptibility of S. aureus. The 56 out of 282 isolates were identified as S. aureus. It is found that 10 workers out of 28 carried S. aureus in their nasal cavity while 4 and 3 workers out of 21 carriered S. aureus in mouth and hands respectively. None of the isolates carried mecA genes and also their antibacterial susceptibility test for methicillin resistance, using cefoxitin $(30 \mu \mathrm{g})$, shown that all the isolates was susceptible to methicillin. In conclusion, the results of the present study indicated that the prevalence of antibiotic resistance of $S$. aureus strains isolated from food handlers was low. However carriage rate of $S$. aureus among food handlers was quite high.
\end{abstract}

Keywords: S. aureus, Food handlers, Methicillin resistance

\section{Background}

Staphylococcus is a genus of the Gram-positive bacteria and the member of the Staphylococcaceae family. In this genus the most common pathogen is Staphylococcus aureus, which having a broad host range. It is widely distributed in nature and is commonly found in the nose, throat, hair and skin of humans and animals. Approximately $20-30 \%$ of healthy people carry this microorganism (Lory 2014; Van Belkum et al. 2009). However, S. aureus is a potentially dangerous pathogen causing a variety of localized or invasive diseases, as well as food poisoning.

Nasal carriage of S. aureus in food handlers is the major risk for staphylococcal food poisoning and because of a big concern for food safety. If the hygiene measures not taken up properly, organism can transferred from contaminated hands to food and can lead to food poisoning by the products of enterotoxigenic strains in this food (Ho et al. 2014). Both epidemiologic and molecular data

\footnotetext{
${ }^{*}$ Correspondence: Ivatansever@hotmail.com

Department of Food Safety and Public Health, Faculty of Veterinary Medicine, Kafkas University, 36100 Kars, Turkey
}

in food poisoning outbreaks have indicated that $S$. aureus carried by food handlers was the source of contamination (Kluytmans et al. 1995; Sivaraman et al. 2009). Therefore it is important to detect $S$. aureus carriage among food handlers to prevent possible food contamination by them resulting in food poisoning.

Antimicrobial resistance is an inevitable consequence of antimicrobial use. Specifically the use of antimicrobials in food animals creates an important source of resistant bacteria. These bacteria can easily be spread to humans through the food supply (Collignon et al. 2009). Staphylococcus aureus can adapt better than any other human pathogen to the antimicrobials. It has demonstrated a unique ability to quickly respond to each new antimicrobial, with the development of a resistance mechanism, starting with penicillin and methicillin (Pantosti et al. 2007). Among S. aureus, methicillin-resistant strain (MRSA) has emerged as a serious life threaten infective agent which does not respond to a lot of antimicrobial treatments. This methicillin resistance strain synthesizes a penicillin binding protein (PBP2a), encoded by the $m e c A$ gene on a mobile genetic element, which has a 
role of counteracting the inhibitory effect of Beta-lactam antibiotics by preventing them from effectively binding to cell wall proteins (Pantosti et al. 2007).

In the present study, we aimed to determine carriage rate of $S$. aureus among food handlers work in catering services in Kars City, Turkey and to investigate their susceptibility to antibacterial agents using disk diffusion methods as well as methicillin resistance by using polymerase chain reaction.

\section{Methods}

\section{Sample collection}

The samples were collected from food handlers who work in catering services in Kars, Turkey. The catering services, 30 staff works in this establishment, prepares and delivers food to dining facilities of 2 academic institutions and some of them also work in services. Samples were obtained using sterile swabs and physiological saline solution from nasal cavities, hands and mouths of same food handlers, which work for service and preparation area. The workers deal with all kinds of meat (except pig meat) and vegetables. Three different swabs were used for one worker. One swab was used to swab areas in between fingers and the wrist area of the both hand and another swab was used to swab the 1-2 $\mathrm{cm}$ inside the anterior nares (one swab for both nares) and another swab used to swab mouth (internal face of cheeks). Sampling from the staff members was performed during their working hours on the same day. The experiment was conducted under the protocol which was approved by Kafkas University, Medicine Faculty, Local Ethical Committee (Decision No: 80576354-050-90/139).

\section{Isolation and identification of Staphylococcus aureus}

Swab samples were streaked onto Baird-Parker Agar (BP, Oxoid CM 0275) with added Egg Yolk Tellurite (Oxoid, SR 0054). After incubation at $37^{\circ} \mathrm{C}$ for $24-48 \mathrm{~h}$, S. aureus suspected colonies (up to five colonies) were selected. The selected colonies were transferred into tubes containing Brain Heart Infusion Broth (BHI, Oxoid, CM375) and incubated at $37^{\circ} \mathrm{C}$ for $24 \mathrm{~h}$. Then transferred to BP agar incubated at $37^{\circ} \mathrm{C}$ for $24-48 \mathrm{~h}$ and then transferred to Nutrient Agar slants (NA, Oxoid CM3) for further testing and then basic identification tests were performed on isolated colonies (ISO 1999; Bennett and Lancette 2001).

\section{Molecular typing of bacterial isolates}

Genomic DNA was extracted from $24 \mathrm{~h}$ cultures in Brain Heart Infusion Broth (Oxoid CM 225) using a DNA extraction kit (Qiagen, 69506, DNeasy Blood and Tissue Kit, Germany) following the manufacturer's instructions.

The each PCR mixture contained 100 ng genomic DNA, $1 \times$ taq buffer (Vivantis, $\mathrm{S}$ buffer with $\mathrm{MgCl}_{2}$
$17.5 \mathrm{mM}$ ), $1 \mathrm{U}$ taq DNA polymerase (Vivantis, PL $1202-5 / \mu \mathrm{l}$ ), $0.2 \mathrm{mM}$ of dNTP mix (Vivantis, NP2406), $0.6 \mathrm{mM}$ of forward and reverse primers (Sentromer/ Turkey) and sterile Hypure water (HyClone-AUM57939) up to final volume of $25 \mu$ l. The sequence of the forward and reverse primer for $S$. aureus $5^{\prime}$-TGA AGT CAA ATA AAT CGC TT GC-3' (Nuc2F) and 5'-CCC TTT TCC ACT AAT TCC TTA TT GT-3' (NucR) (Perillo et al. 2012; Veras et al. 2008; Zhang et al. 2004).

The method suggested by Perillo et al. (2012) has been applied with some modifications in order to identify the S. aureus (nuc) genes. PCR was performed in a Biometra Thermocycler using the following conditions: $95{ }^{\circ} \mathrm{C}$ for $2 \mathrm{~min}$ (initial cycle), followed by 30 cycle of $95^{\circ} \mathrm{C}$ for $30 \mathrm{~s}$, $50{ }^{\circ} \mathrm{C}$ for $30 \mathrm{~s}$ and $72{ }^{\circ} \mathrm{C}$ for $30 \mathrm{~s}$. ATCC 14458 and ATCC $43300 \mathrm{~S}$. aureus strains were used as positive controls for PCR-based analysis. As negative control, Hypure water was used instead of template DNA. The PCR products were loaded onto a $2 \%$ agarose gel containing ethidium bromide followed by electrophoresis using a $100 \mathrm{bp}$ DNA ladder in TAE buffer at $90 \mathrm{~V} 60 \mathrm{~min}$ following visualization by an UV illuminator.

\section{Detection of methicillin resistance}

The presence of the mecA gene was investigated by PCR. Sequences of the forward and reverse primers were: 5'-ACT GCT ATC CAC CCT CAA AC-3' (GMECAR-1) and $5^{\prime}$-CTG GTG AAG TTG TAA TCT GG-3' (GMECAR-2) (Mehrotra et al. 2000). The PCR parameters were an initial denaturation at $94{ }^{\circ} \mathrm{C}$ for $5 \mathrm{~min}$, followed by 35 cycles of amplification at $94{ }^{\circ} \mathrm{C}$ for $2 \mathrm{~min}, 57^{\circ} \mathrm{C}$ for $2 \mathrm{~min}$, $72{ }^{\circ} \mathrm{C}$ for $1 \mathrm{~min}$ and $72{ }^{\circ} \mathrm{C}$ for $7 \mathrm{~min}$ (Mehrotra et al. 2000).

\section{Antimicrobial susceptibility}

Antimicrobial susceptibility test of the $S$. aureus isolates was performed by agar disk diffusion method according to the Clinical and Laboratory Standards Institute (CLSI 2014) and European Committee on Antimicrobial Susceptibility Testing (EUCAST 2013). All tests were performed on Mueller-Hinton agar. The bacterial suspension having visually equivalent turbidity to $0.5 \mathrm{McFar}-$ land standards were prepared. The swab stick was dipped into bacterial suspension then took out and squeezed on the wall of the test tube to discard extra suspension. The surface of agar was then lightly and uniformly inoculated using this swab. Four antibiotic disks were placed for each plate. The plates were incubated at $35{ }^{\circ} \mathrm{C}$ for $24 \mathrm{~h}$. After $24 \mathrm{~h}$, inhibition zones on agar plate were measured. Results were recorded and graded as resistance $(R)$ intermediate resistance (IR) and sensitive (S) according to the reference zone of inhibition of particular antibiotic (EUCAST 2015). S. aureus ATCC 25293 was used as a quality control standard. Following antibiotics were used 
susceptibility test: netilmicin $(30 \mu \mathrm{g})$, gentamicin $(10 \mu \mathrm{g})$, amikacin $(30 \mu \mathrm{g})$, erythromycin $(15 \mu \mathrm{g})$, imipenem $(10 \mu \mathrm{g})$, ciprofloxacin $(5 \mu \mathrm{g})$, cefoxitin $(30 \mu \mathrm{g})$, tetracycline $(30 \mu \mathrm{g})$, chloramphenicol $(30 \mu \mathrm{g})$, cefazolin $(30 \mu \mathrm{g})$, trimethoprim $(5 \mu \mathrm{g})$, trimethoprim/sulfamethoxazole $(25 \mu \mathrm{g})$, mupirocin $(200 \mu \mathrm{g})$, clindamycin $(2 \mu \mathrm{g})$.

\section{Results}

A total of 282 Staphylococcus spp. isolates, 112 isolates from nasal cavity swabs, 92 isolates from hand and 78 isolates from mouth swabs were examined for $S$. aureus (nuc) genes (Table 1). The 56 (20\%) out of 282 isolates were identified as $S$. aureus which including 32 (57 \%) isolates from the nasal cavity, $13(23 \%)$ isolates from mouth and 11 (20\%) isolates from hands of workers.

It is found that 10 workers out of 28 carried S. aureus in their nasal cavity while 4 and 3 workers out of 21 carried $S$. aureus in mouth and hands respectively.

The results of antimicrobial resistance of $S$. aureus isolates were shown in Table 2. None of the isolates carried $m e c A$ genes and also their antibacterial susceptibility test

Table 1 Distribution of isolates according to the samples

\begin{tabular}{llll}
\hline Samples & $\begin{array}{l}\text { Number } \\
\text { of person }\end{array}$ & $\begin{array}{l}\text { Staphylococcus } \\
\text { spp. }\end{array}$ & $\begin{array}{l}\text { Staphylococcus } \\
\text { aureus }\end{array}$ \\
\hline Nasal cavity & 28 & 112 & 32 \\
Hand & 21 & 92 & 13 \\
Mouth & 21 & 78 & 11 \\
Toplam & $28^{\mathrm{a}}$ & 282 & 56 \\
\hline
\end{tabular}

${ }^{a}$ From same 21 person nasal cavity, hand and mouth samples were collected for methicillin resistance, using cefoxitin $(30 \mu \mathrm{g})$, showed that all the isolates was susceptible to methicillin.

\section{Discussion}

Studies from different countries have indicated that food handlers, owing to their 20-30\% carriage rate, have been one of the major sources of food contamination with $S$. aureus (Lory 2014; Van Belkum et al. 2009). In this study $20 \%$ of isolates were identified as S. aureus and the percentage rate were higher in nasal cavity isolates $(57 \%)$ than mouth (23\%) and hand (20\%) ones. Results showed that, nasal carriage rate among food handlers was $36 \%$ (10 people out of 28 ), however mouth and hand carriage rate lower compered to nasal carriage rate, 19 and $14 \%$ (4 and 3 people out of 21) respectively. Only in one worker, nasal cavity, mouth and hand samples found to be positive for $S$ aureus. While one worker's hand and nasal cavity samples shown positive results for S. aureus, one worker's mouth and nasal cavity samples were positive for $S$. aureus. It is possible that the worker can contaminate or carries one strain from her/his nasal cavity to her/ his mouth or/and hand or vice versa. Earlier study (Sezer et al. 2015) report that carriage rate of $S$. aureus among food handlers was $79 \%$. However, there are other studies indicating much lower prevalence among food handlers in Turkey. Nasal carriage rate of $S$. aureus among food workers in Turkey were determined as follows; $3 \%$ in Antalya, 7 \% in Kütahya, $15 \%$ in Bursa, $15 \%$ in Konya, 23 \% in Şanlıurfa (Sepin-Özen et al. 2013). Nasal carriage rates of $S$. aureus show a large variation among studies, cities and countries. In a study done in Kuwait (Udo et al. 2009) the carriage rate was reported as $53 \%$,

Table 2 Antibacterial resistance of $S$. aureus isolates obtained from food handlers

\begin{tabular}{|c|c|c|c|c|c|c|}
\hline \multirow[t]{2}{*}{ Antibiotics } & \multicolumn{2}{|c|}{ Mouth $(n=13)$} & \multicolumn{2}{|c|}{ Hand $(n=11)$} & \multicolumn{2}{|c|}{ Nose $(n=32)$} \\
\hline & $\mathrm{R}(\%)$ & IR (\%) & $\mathrm{R}(\%)$ & IR (\%) & $\mathrm{R}(\%)$ & IR (\%) \\
\hline Netilmicin & - & - & - & - & - & - \\
\hline Gentamicin & - & - & - & - & - & - \\
\hline Amikacin & - & - & - & - & - & - \\
\hline Erythromycin & $1(8)$ & - & - & - & - & - \\
\hline Imipenem & - & - & - & - & - & - \\
\hline Ciprofloxacin & - & - & - & - & - & - \\
\hline Cefoxitin & - & - & - & - & - & - \\
\hline Tetracycline & - & $1(8)$ & $1(9)$ & - & - & - \\
\hline Chloramphenicol & - & - & - & - & - & - \\
\hline Cephazolin & - & - & - & - & - & - \\
\hline Trimethoprim & - & $1(8)$ & - & - & $2(6)$ & $2(6)$ \\
\hline Trimethoprim/sulfamethoxazole & - & - & - & - & - & - \\
\hline Mupirocin & - & $2(15)$ & - & - & - & - \\
\hline Clindamicin & - & - & - & - & - & - \\
\hline
\end{tabular}

$R$ resistance, $I R$ intermediate resistance 
while in another investigation conducted in Hong Kong (Ho et al. 2014) it was $23 \%$ among food handlers. Sivaraman et al. (2009) reviewed the extent and variability of nasal carriage rate and suggested that prevalence varies in industrialized nations from 26 to $35 \%$ of the population, ethnicity and availability of medical care affect the carriage levels and developed nations have a higher percentage of carriage than the developing countries. In our study we found that a higher percentage of carriage rate than other studies done in Turkey. But, we looked at special group of people which work in catering services and they deal with food all the times. So it is possible that this food might contaminate them with these bacteria. Contradicted results may reflect variation in different populations living in different geographical regions and at the same time, workers work in different foods (meat, dairy products, vegetables and grains etc.). Supporting this theory Ho et al. (2014) reported that colonization rates were considerably higher in workers handling raw meats $(30 \%)$ than in non-exposed workers (13\%). Furthermore, differences in results could be based on various factors such as cleaning habits of workers, level of education, the hygiene of utensils-equipment and the environment the food handlers is working in and the regulations on inquest (Sivaraman et al. 2009; Ho et al. 2014; El-Shenawy et al. 2014). El-Shenawy et al. (2014) conducted cross sectional study of skin carriage (hands and face swabs) and found that 75 (38 \%) of the 200 person were positive for the presence of $S$. aureus. Udo et al. (1999) identified 32 (18 \%) S. aureus out of 174 isolates from the hands of healthy food handlers. They also found much higher results (92\%) from nasal cavity. Similarly, in our study, mouth and hand carriage rate much lower than nasal carriage rate among food handlers. Extended hygienic measures should be applied in food plants and restaurants to prevent food contamination with these bacteria by food handlers.

In the second part of our study, antimicrobial resistance profile of isolates has been investigated. The World Health Organisation has divided antimicrobials in three categories as critically important, highly important and important according to their importance in human medicine (Collignon et al. 2009). In this study, six critically important antimicrobials (namely; gentamicin, netilmicin, imipenem, amikacin, erythromycine, ciprofloxacin), six highly important antimicrobials (cefazolin, trimethoprim, trimethoprim/sulfamethoxazole, tetracycline and cefoxitin) and two important antimicrobials (clindamycin, mupirocin) were tested. One isolates found to be resistant to critically important antimicrobials and eight isolates were resistant to two highly important antimicrobials. Multi drug resistance (MDR) was determined from a mouth isolates, which was resistant to erythromycin and mupirocin but none of the isolates were methicillin resistant. Sepin-Özen et al. (2013) reported that percentage of MRSA as 5.3 among food handlers work in Antalya, Turkey. In other study, nasal carriage rate of MRSA reported as $18 \%$ (6 out of 34 farm workers) among farm workers in Turkey (Hazımoğlu 2011). In a study conducted on food handlers it was reported that only one isolate out of 200 isolates (Udo et al. 2009) was methicillin resistant. Similarly, Kamal et al. (2013) also found that none of the hand swabs of $S$. aureus isolates from the dairy workers and food handlers was positive for the mecA gene. Collignon et al. (2009) reported that although it currently represents a low proportion of the total MRSA infections that occur in people, there are an increasing number of reports of animal-derived MRSA especially from pigs, causing community-onset infection in people.

\section{Conclusion}

In conclusion, the results of the present study indicated that the prevalence of antibiotic resistance of $S$. aureus isolated from food handlers was low. However, the carriage rate of $S$. aureus among food handlers was quite high. Since research findings and investigations have suggested that staphylococcal food borne disease is largely due to faulty food handling practices, it is important to give proper training to food handlers in order to prevent the contamination of foods.

\section{Authors' contributions}

LV, ÇS conceived of the study, and participated in its design and coordination. $N B$, ÇS and LV carried out the laboratory work of the study. NB helped to draft the manuscript. All authors read and approved the final manuscript.

\section{Competing interests}

The authors declare that they have no competing interests.

Received: 26 November 2015 Accepted: 4 May 2016

Published online: 12 May 2016

\section{References}

Bennett RW, Lancette GA (2001) Staphylococcus aureus. In: FDA bacteriological analytical manual online, chapter. 12. Date: 30.01.2014 http://www.cfsan. fda.gov/

Clinical and Laboratory Standards Institute (CLSI) (2014) Performance standards for antimicrobial susceptibility testing; 24th information supplement. M100-S24

Collignon P, Powers JH, Chiller TM, Aidara-Kane A, Aerestrup FM (2009) World Health Organisation ranking of antimicrobials according to their importance in human medicine: a critical step for developing risk management strategies for the use of antimicrobials in food production animals. Clin Infect Dis 49:132-141

El-Shenawy M, Tawfeek M, El-Hosseiny L, El-Shenawy M, Farag A, Baghdadi $\mathrm{H}_{\text {, }}$ Saleh O, Manes J, Soriano JM (2014) Cross sectional study of skin carriage and enterotoxigenicity of Staphylococcus aureus among food handlers. Open J Med Microbiol 4:16-22

European Committee on Antimicrobial Susceptibility Testing (EUCAST) (2013) Development of the EUCAST disk diffusion antimicrobial susceptibility 
testing method and its implementation in routine microbiology laboratories

European Committee on Antimicrobial Susceptibility Testing (EUCAST) (2015) Break point tables for interpretation of MIC and zone diameter. Version 5.0, valid from 2015-01-01

Hazımoğlu Ş (2011) Investigation of Panton-Valentine Leukocidine (PVL) genes in Staphylococcus aureus isolates. PhD thesis. Adnan Menderes Üniversitesi, Sağ lık Bilimleri Enstitüsü

Ho J, O'donoghue MM, Boost MV (2014) Occupational exposure to raw meat: a newly-recognized risk factor for Staphylococcus aureus nasal colonization amongst food handlers. Int J Hyg Environ Health 217:347-353

International Organization for Standardization. ISO 6888-1 (1999) Microbiology of food and animal feeding stuffs. Horizontal method for the enumeration of coagulase-positive staphylococci (Staphylococcus aureus and other species)-part 1: technique using Baird-Parker agar medium. ISO, Geneva, Switzerland

Kamal RM, Bayoumi MA, Abd El Aal SFA (2013) MRSA detection in raw milk, some dairy products and hands of dairy workers in Egypt, a mini-survey. Food Control 33:49-53

Kluytmans J, Van Leeuwen W, Goessens W, Hollis R, Messer S, Herwaldt L, Bruining H, Heck M, Rost J, Van Leeuwen N, Van Belkum A, Verbrugh H (1995) Food-initiated outbreak of methicillin-resistant Staphylococcus aureus analyzed by pheno- and genotyping. J Clin Microbiol 33:1121-1128

Lory S (2014) The Family Staphylococcaceae. In: Rosenberg E (ed) The Prokaryotes-Firmicutes and Tenericutes, 4th edn. Springer, Berlin

Mehrotra M, Wang G, Johnson WM (2000) Multiplex PCR for detection of genes for Staphylococcus aureus enterotoxins, exfoliative toxins, toxic shock syndrome toxin 1, and methicillin resistance. J Clin Microbiol 38:1032-1035

Pantosti A, Sanchini A, Monaco M (2007) Review: mechanisms of antibiotic resistance in Staphylococcus aureus. Future Microbiol 2:223-234

Perillo J, Ceccarelli D, Spagnoletti M, Lollai S, Cappuccinelli P, Colombo MM (2012) Molecular characterization of enterotoxigenic and borderline oxacillin resistant Staphylococcus strains from ovine milk. Food Microbiol 32:265-273

Sepin-Özen N, Tuğlu-Ataman Ş, Seyman D, Aldağ H, Emek M (2013) Investigation of nasal Staphylococcus aureus carriage and methicillin resistance rates with three different methods in food handlers working at Antalya. Turk Hij Den Biyol Derg 70:51-58

Sezer Ç, Çelebi Ö, Aksoy A, Vatansever L (2015) Food Handlers: a bridge in the journey of enterotoxigenic MRSA in Food. J Verbr Lebensm 10:123-129

Sivaraman K, Venkataraman N, Cole AM (2009) Staphylococcus aureus nasal carriage and its contributing factors. Future Microbiol 4:999-1008

Udo EE, Al-Bustan MA, Jacob LE, Chugh TD (1999) Enterotoxin production by coagulase-negative staphylococci in restaurant workers from Kuwait City may be potential cause of food poisoning. J Med Microbiol 48:819-823

Udo EE, Al-Mufti S, Albert MJ (2009) The prevalence of antimicrobial resistance and carriage of virulence genes in Staphylococcus aureus isolated from food handlers in Kuwait City restaurants. BMC Res Notes 2:108. http:// www.biomedcentral.com/1756-0500/2/108

Van Belkum A, Verkaik NJ, De Vogel CP, Boelens HA, Verveer J, Novwen JL, Verbrugh HA, Wertheim HF (2009) Reclassification of Staphylococcus aureus nasal carriage types. J Infect Dis 199:1820-1826. doi:10.1086/599119

Veras JF, Do Carmo LS, Tong LC, Shupp JW, Cummings C, Dos Santos DA, Cerqueira MM, Cantini A, Nicoli JR, Jett M (2008) A study of the enterotoxigenicity of coagulase-negative and coagulase-positive staphylococcal isolates from food poisoning outbreaks in Minas Gerais, Brazillian. Int J Infect Dis 12:410-415

Zhang K, Sparling J, Chow BL, El Sayed S, Hussain Z, Church DL, Gregson DB, Louie T, Conly JM (2004) New quadruplex PCR assay for detection of methicillin and mupirocin resistance and simultaneous discrimination of Staphylococcus aureus from coagulase-negative staphylococci. J Clin Microbiol 42:4947-4955. doi:10.1128/JCM.42.11.4947-4955.2004

\section{Submit your manuscript to a SpringerOpen ${ }^{\circ}$ journal and benefit from:}

- Convenient online submission

- Rigorous peer review

- Immediate publication on acceptance

- Open access: articles freely available online

- High visibility within the field

- Retaining the copyright to your article

Submit your next manuscript at $\boldsymbol{\nabla}$ springeropen.com 